\title{
Isolation and Characterization of Lactic Acid Bacteria Isolated from Fermented Food of North-West Himalayas
}

\author{
Heenu Sharma* (D) and Jasveen Bajwa \\ Department of Biotechnology, Chandigarh University, Mohali - 140 413, Punjab, India.
}

\begin{abstract}
Lactic acid bacteria (LAB) are ubiquitous and are one of the major microbial groups involved in the fermentation of various types of food. They are the most dominant microbes present in milk or milk products and fermented foods where they play vital roles in both the manufacturing and ripening processes. Kaladhi is one of the traditional fermented products of the North-West Himalaya region. It is a hard and dry cheese. In our research, a total of 9 isolates was isolated and was evaluated on the basis of preliminary characterization viz. morphological as well as biochemical characterization and was examined for their antagonistic activity against following pathogens. On the basis of their maximum antagonistic potential against food-borne pathogenic bacteria, isolate $\mathrm{K} 1$ is characterized by $16 \mathrm{~S}$ rRNA sequencing. The isolate was identified as Lactobacillus paracasei subsp. Tolerans strain NBRC $15906 \mathrm{~K} 1$ |MN814072|.This research was aimed to study the unexplored microflora of Kaladhi and to determine its probiotic potential.
\end{abstract}

Keywords: Lactic acid bacteria, rRNA, Kaladhi, Probiotics, Lactobacillus

*Correspondence: sharmaheenu507@gmail.com

(Received: June 22, 2021; accepted: July 30, 2021)

Citation: Sharma H, Bajwa J. Isolation and Characterization of Lactic Acid Bacteria Isolated from Fermented Food of North-West Himalayas. J Pure Appl Microbiol. 2021;15(3):1567-1572. doi: 10.22207/JPAM.15.3.50

(C) The Author(s) 2021. Open Access. This article is distributed under the terms of the Creative Commons Attribution 4.0 International License which permits unrestricted use, sharing, distribution, and reproduction in any medium, provided you give appropriate credit to the original author(s) and the source, provide a link to the Creative Commons license, and indicate if changes were made. 


\section{INTRODUCTION}

Microorganisms are present almost in every habitat because of their ubiquitous property. Among them, some microbes exhibit various beneficial properties viz. in improving human health or in food production. Probiotics are one of those microbes that have an extensive role in maintaining the host's health and controlling some diseases. According to FAO/ WHO, probiotics are: "Live microorganisms which when administered in adequate amounts confer a health benefit on the host". They are also considered as "friendly bacteria" or "good bacteria". Probiotic bacteria are non-pathogenic and non-toxic microbes and show important functions for well being and health of the host ${ }^{1}$. Therefore, it's important to maintain the ecological flora in order to prevent diseases, especially infections of the gastrointestinal tract ${ }^{2,3}$.

The fermented foods are one of the major sources of probiotics 4 . The fermented foods are that food that has undergone a lactic fermentation process in which the natural microflora feeds upon the sugar and starch present in the food creating lactic acid. Traditional fermented food products are important in nutrition as sources of carbohydrates, proteins, fibers, minerals and vitamins ${ }^{4}$.

In India, about 50-55\% of milk is converted into several traditional products utilizing various processes such as fermentation, coagulation and desiccation ${ }^{5}$. Kaladhi is one of the culinary preparations of dairy in Jammu and Kashmir state ${ }^{6}$.

Kaladhi is a traditional fermented food product of state Jammu and Kashmir (Fig. 1). It is prepared by coagulating the milk and the coagulum

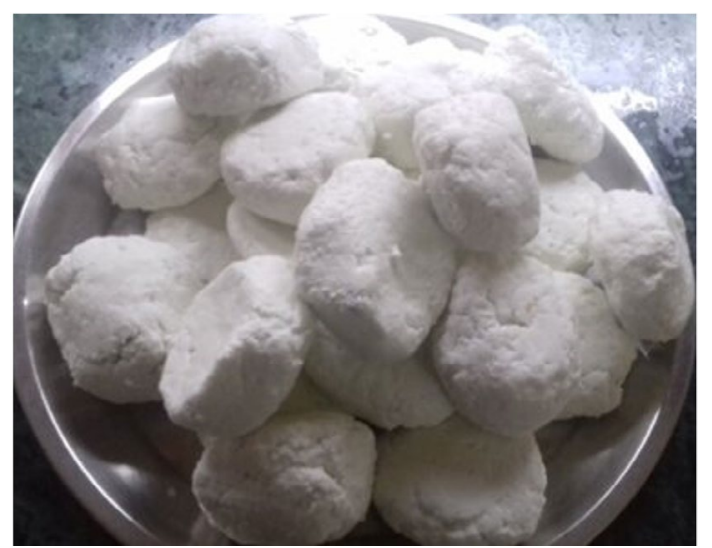

Fig. 1. Kaladhi- A traditional fermented food of NorthWest Himalayas region was working out into the pat and finally small balllike product is prepared which are manually spread out to a circular shape and then dried into the sun light to absorb the moisture. Ahmad in his studies defined kaladhi as an acid coagulant product that is prepared by directly acidifying the milk with some coagulating agents like organic acids ${ }^{7}$. The product is made either from buffalo's or cow's milk. Kaladhi is also known as 'Maush kraer' in Kashmir division of the state. Kaladhi doesn't require the use of rennet or any starter during its preparation. The most popular coagulant used traditionally for the Kaladhi preparation is tartaric acid but either citric acid or whey water can also be used to coagulate the raw or boiled milk. It is consumed after frying it with some suitable frying medium along with spices and condiments. This product is believed to possess anti-diarrheal and anti-cold properties besides being a salubrious food, thus have tremendous market potential ${ }^{8}$.

Nutritional composition of Kaladhi includes 412kj Energy, 3.3gms of Carbohydrate, 2.67 gms. Sugar, 11.12 gms of Proteins, equiv. $5 \%$ of Vitamin A, $83 \mathrm{mg}$ Calcium, $0.07 \mathrm{mg}$ Iron, $8 \mathrm{mg}$ Magnesium, 159mg Phosphorus, $104 \mathrm{mg}$ Potassium, $3.64 \mathrm{mg}$ Sodium and $0.40 \mathrm{mg}$ Zinc $^{16}$. So Kaladhi possess so many nutrients and can be healthy to consume but because of its low $\mathrm{pH}$, its shelf life is limited caused by various microbes especially molds ${ }^{17}$. Kaladhi cheese can be a source to isolate novel probiotics but unpasteurized cheese also produces food borne- pathogens like S. aureus, L. monocytogenes, Salmonella and $E$. coli strains ${ }^{18}$.

Raw milk and traditional fermented foods act as highly rich environments for a diverse and indigenous microbiota, including $\angle A B$, that further contribute to the bio-preservation and development of nutraceutical or functional final products. Among LAB, the Lactobacillus strains are predominantly exploited to acquire the probiotic properties as well as utilized in the form of adjunct cultures. Attributing to their historical view of safe use and natural presence in the human gut, they are generally regarded as safe (GRAS). Moreover, several species of Lactobacillus have attained the status of qualified presumption of safety (QPS) status.

Such food products act as an alternative source of novel probiotic candidates that can 
be utilized for the manufacturing of functional probiotic products that are further protected from gastrointestinal stress. So these foods can be a way to represent novel candidates of probiotics.

As the microflora of this product is not that much explore so in this research an attempt was made to isolate the potential probiotic strains in order to meet the promising results as therapeutic effects.

\section{MATERIALS AND METHODS Chemicals}

All the chemicals utilized in this study were obtained from HI-Media and of analytical grade.

\section{Sample collection}

Samples of Kaladhi were collected from the North-West Himalayas region mentioned in Fig. 1.

\section{Isolation of LAB}

$1 \mathrm{gm}$ of the sample was diluted with $9 \mathrm{ml}$ of sterile water and homogenized for the 60s. The homogenates were followed by serial dilution with sterile distilled water and then plated on the MRS (De Man, Rogosa, and Sharpe media) plates. Incubation was given at $37^{\circ} \mathrm{C}$ for $24 \mathrm{hrs}$. After incubated plates, individual similar colonies were selected and further purified by using the streak method on the selected medium ${ }^{13}$.

\section{Phenotypic and biochemical characterization}

Preliminary identification of LAB strains was done based on their potential to grow in MRS broth, the positive gram staining, absence of endospores. MRS is a media used for the cultivation of Lactobacillus species. Biochemical studies of strains were done to evaluate the production of Catalase, oxidase, methyl red voges proskauer (MR-VP test), casein hydrolysis and starch hydrolysis tests ${ }^{14}$.

\section{Genotypic characterization}

Molecular Identification of the Selected LAB Isolates: The bacterial strains were identified at the genomic level by using the 16s rRNA gene technique.

\section{Antibacterial assay}

The antagonistic activity of each isolates against spoilage causing microbes i.e pathogenic test indicators were analyzed by using the agar well diffusion assay. The results were examined in the terms of zone of inhibition around the wells. Test indicators used are Klebseilla pneumonae, Enterococcus faecalis, St L. paracasei subsp. Tolerans reptococcus dysgalactiae and Pseudomonas aeruginosa ${ }^{9}$.

\section{Haemolytic activity}

The haemolytic activity of potential probiotic isolates was determined by the method of Marakoudakis ${ }^{10}$. The isolates were grown on respective broth for $37^{\circ} \mathrm{C}$ for $24 \mathrm{~h}$ and were streaked on the blood agar plates that were supplemented with $5 \%(\mathrm{v} / \mathrm{v})$ of whole human blood and the plates were incubated at their respective temperatures then examined on the basis of zones ${ }^{10}$.

\section{Inter compatibility testing}

Inter compatibility of the bacterial isolates was checked by using the Cross streak method $^{11}$.

\section{Acid tolerance assay}

Survival of lactobacilli at low $\mathrm{pH}$ was checked by inoculating $1 \%$ of culture in $20 \mathrm{ml}$ of respective broth with the $\mathrm{pH}$ of 2.0 and 5.0 and incubation was given at $37^{\circ} \mathrm{C}$ for $24 \mathrm{hrs}$. Growth was measured by taking optical density at $620 \mathrm{~nm}^{12}$.

\section{Co-aggregation assay}

Co-aggregation ability of the strains to form a barrier against pathogens was assessed according to Del $\operatorname{Re}^{19}$.

\section{RESULTS AND DISCUSSIONS Isolation and characterization of $L A B$}

A total of 9 isolates were isolated from the sample Kaladhi and were recognized on the basis of morphological characteristics and biochemical analysis. Physiological and Biochemical characterization of the microbial isolates had been done and their characteristics were noted down in Table 1-2. Most of the microbial strains were off white Gram-positive, rod-shaped and some of them gave negative Catalase and oxidase results and hence considered as lactobacilli. All the isolates showed negative results of MR-VP test and were not able to hydrolyse amylase

\section{Molecular Identification of the Isolates}

The best-selected LAB isolates on the basis of their antagonistic effect against selected pathogenic bacteria were identified at the genomic level by 16 srRNA sequence analysis. The $16 \mathrm{~S}$ 
Table 1. Morphological Characteristic of microbial isolates

\begin{tabular}{lllll}
\hline No. & Isolate & Source & Color & Surface \\
\hline 1 & K1 & Kaladhi & White & Round \\
2 & K2 & Kaladhi & Cream & Round \\
3 & K3 & Kaladhi & Cream & Round \\
4 & K4 & Kaladhi & Cream & Smooth \\
5 & K5 & Kaladhi & White & Round \\
6 & K6 & Kaladhi & White & Round \\
7 & K7 & Kaladhi & White & Round \\
8 & K8 & Kaladhi & Cream & Round \\
9 & K9 & Kaladhi & Cream & Smooth \\
\hline
\end{tabular}

rRNA sequence of isolate K1 showed its close resemblance $(98.7 \%)$ with other Lactobacillus paracasei strains available in the GenBank database (National Centre for Biotechnology Information (NCBI)). Therefore, this isolate was designated as L. paracasei subsp. Tolerans K1. The sequence of K1 was deposited in GenBank with accession number MN814072. Phylogenetic relationship of $L$. paracasei subsp. Tolerans K1 based on $16 \mathrm{~S}$ rRNA sequencing analysis is shown in Fig. 2.

\section{Antimicrobial activity}

Many of the potential LAB isolates exhibited antibacterial effect towards food spoilage as well as pathogenic bacteria viz. Klebseilla pneumonae, Enterococcus faecalis, Streptococcus dysgalactiae and Pseudomonas aeruginosa. Isolates $\mathrm{K}-1$ and $\mathrm{K}-3$ inhibited most of the pathogenic micro-organisms. The data is shown in Table 3.

\section{Hemolytic activity}

The hemolytic activity of isolates was
Table 2. Biochemical characteristics of microbial isolates

\begin{tabular}{cccccc}
\hline No. Isolate & $\begin{array}{c}\text { Grams } \\
\text { reaction }\end{array}$ & $\begin{array}{c}\text { Catalase } \\
\text { test }\end{array}$ & $\begin{array}{c}\text { Starch } \\
\text { hydrolysis } \\
\text { test }\end{array}$ & $\begin{array}{c}\text { Casein } \\
\text { hydrolysis } \\
\text { test }\end{array}$ \\
\hline 1 & $\mathrm{~K} 1$ & $+\mathrm{ve}$ & $-\mathrm{ve}$ & $-\mathrm{ve}$ & $-\mathrm{ve}$ \\
2 & $\mathrm{~K} 2$ & $+\mathrm{ve}$ & $-\mathrm{ve}$ & $-\mathrm{ve}$ & $+\mathrm{ve}$ \\
3 & $\mathrm{~K} 3$ & $+\mathrm{ve}$ & $-\mathrm{ve}$ & $-\mathrm{ve}$ & $+\mathrm{ve}$ \\
4 & $\mathrm{~K} 4$ & $+\mathrm{ve}$ & $+\mathrm{ve}$ & $-\mathrm{ve}$ & $+\mathrm{ve}$ \\
5 & $\mathrm{~K} 5$ & $+\mathrm{ve}$ & $+\mathrm{ve}$ & $-\mathrm{ve}$ & $-\mathrm{ve}$ \\
6 & $\mathrm{~K} 6$ & $-\mathrm{ve}$ & $-\mathrm{ve}$ & $-\mathrm{ve}$ & $-\mathrm{ve}$ \\
7 & $\mathrm{~K} 7$ & $-\mathrm{ve}$ & $-\mathrm{ve}$ & $-\mathrm{ve}$ & $-\mathrm{ve}$ \\
8 & $\mathrm{~K} 8$ & $+\mathrm{ve}$ & $-\mathrm{ve}$ & $-\mathrm{ve}$ & $-\mathrm{ve}$ \\
9 & $\mathrm{~K} 9$ & $+\mathrm{ve}$ & $-\mathrm{ve}$ & $-\mathrm{ve}$ & $-\mathrm{ve}$ \\
\hline
\end{tabular}

recorded by the observation of a clear zone of hydrolysis around the bacterial colonies ( $\beta$-haemolysis), a partial hydrolysis or greenish zone shows $\alpha$-haemolysis, or no reaction ( $\gamma$ haemolysis). No zone is shown by any isolates in our present study which shows that the isolated isolates can be consumed by humans or animals in any form.

\section{Inter compatibility testing}

This test was determined by the cross streak method. It was done to check the intercompatibility of strains in order to formulate the probiotic consortia. Every strain showed $100 \%$ compatibility with each other.

\section{Acid tolerance assay}

As $\mathrm{pH}$ medium of the gastrointestinal tract is acidic, so in order to survive in a raucous environment of the gastrointestinal tract, probiotic strains must show resistance to low $\mathrm{pH}$. So the effect of acidic $\mathrm{pH}$ was studied to determine the

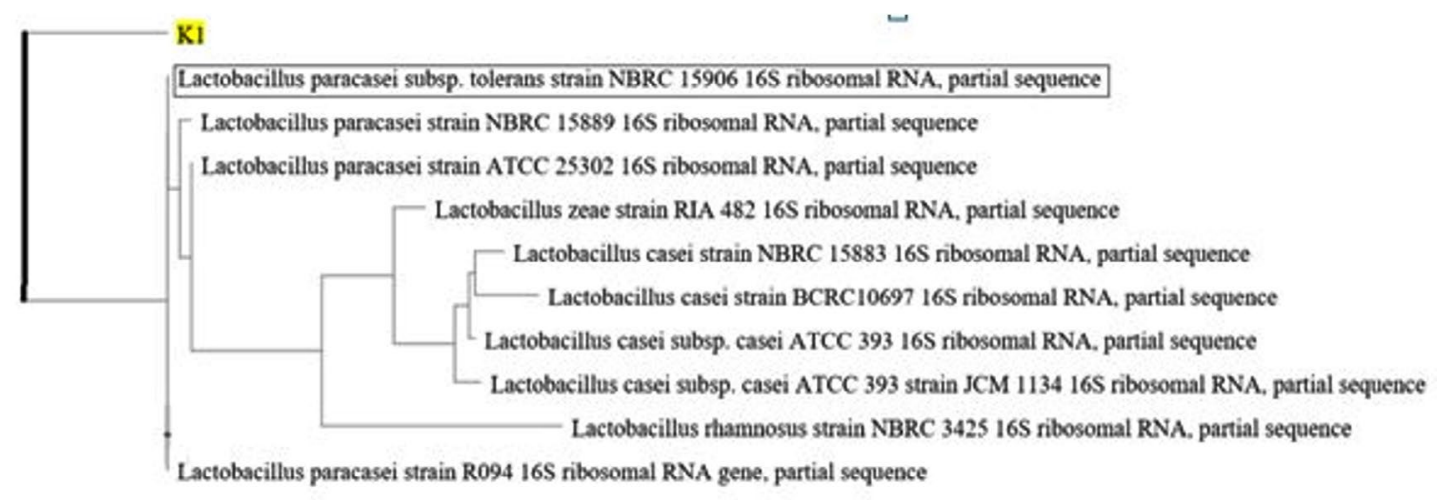

Fig. 2. Phylogenetic relationship of $L$. paracasei subsp. Tolerans K1 based on $16 \mathrm{~S}$ rRNA sequencing analysis

\begin{tabular}{lll}
\hline Journal of Pure and Applied Microbiology & $1570 \quad$ www.microbiologyjournal.org
\end{tabular}


Table 3. Screening of probiotic isolates on the basis of their antagonistic pattern against pathogens by disc diffusion method

\begin{tabular}{ccccccccc}
\hline No. Isolate Source & $\begin{array}{c}\text { K.pneumonae } \\
(\mathrm{mm})\end{array}$ & $\begin{array}{c}\text { E.faecalis } \\
(\mathrm{mm})\end{array}$ & $\begin{array}{c}\text { S.dysgalactiae } \\
(\mathrm{mm})\end{array}$ & $\begin{array}{c}\text { P.aeruginosa } \\
(\mathrm{mm})\end{array}$ & $\begin{array}{c}\text { Mean } \\
(\mathrm{mm})\end{array}$ & $\begin{array}{c}\text { Percent } \\
\text { Inhibition } \\
\text { (\%) }\end{array}$ \\
\hline 1 & & & & & & & & \\
2 & K1 & Kaladhi & 16 & 13 & 12 & - & 10.25 & $75 \%$ \\
3 & K3 & Kaladhi & - & 11 & - & - & 2.75 & $25 \%$ \\
4 & K4 & Kaladhi & - & - & - & - & 0 & $0 \%$ \\
5 & K5 & Kaladhi & 12 & - & - & - & 3 & $25 \%$ \\
6 & K6 & Kaladhi & - & - & - & - & 4 & $25 \%$ \\
7 & K7 & Kaladhi & - & 16 & - & - & 0 & $0 \%$ \\
8 & K8 & Kaladhi & 15 & 11 & - & - & 2.5 & $25 \%$ \\
9 & K9 & Kaladhi & 13 & - & - & - & 9.75 & $75 \%$ \\
\hline
\end{tabular}

Table 4. Effect of different $\mathrm{pH}$ on strains at OD $620 \mathrm{~nm}$

\begin{tabular}{|c|c|c|c|c|c|}
\hline \multirow[t]{2}{*}{ No. } & \multirow[t]{2}{*}{ Isolate } & \multicolumn{2}{|c|}{$\mathrm{pH} 2$} & \multicolumn{2}{|c|}{$\mathrm{pH} 5$} \\
\hline & & $\begin{array}{l}\text { O.D after } \\
24 \text { hour }\end{array}$ & $\begin{array}{l}\text { O.D after } \\
48 \text { hour }\end{array}$ & $\begin{array}{l}\text { O.D after } \\
24 \text { hour }\end{array}$ & $\begin{array}{l}\text { O.D after } \\
48 \text { hour }\end{array}$ \\
\hline 1 & K1 & 0.489 & 1.160 & 0.710 & 0.561 \\
\hline 2 & $\mathrm{~K} 2$ & 0.211 & 0.177 & 0.450 & 0.532 \\
\hline 3 & K3 & 0.283 & 0.191 & 0.301 & 0.481 \\
\hline 4 & K4 & 0.366 & 0.113 & 0.410 & 1.830 \\
\hline 5 & K5 & 0.2770 & 0.201 & 0.361 & 0.374 \\
\hline 6 & K6 & 0.210 & 0.197 & 0.413 & 1.910 \\
\hline 7 & K7 & 0.401 & 0.298 & 1.471 & 0.620 \\
\hline 8 & K8 & 0.129 & 0.075 & 0.521 & 0.601 \\
\hline 9 & K9 & 0.393 & 0.163 & 0.951 & 1.590 \\
\hline
\end{tabular}

potential of strains at low $\mathrm{pH}$ of the stomach. So in this experiment, at $\mathrm{pH} 2 \mathrm{k} 1$ strain showed excellent results after the incubation of 48 hours. Table 4 shows the result of the acid tolerance assay of all strains.

\section{Co-aggregation}

Co-aggregation ability is the process by which 2 strains attached to one another via specific molecules. Probiotic strains shows Co-aggregation activity against pathogens by forming a barrier and thus prevents colonization. Co-aggregation activity of probiotic strains was evaluated against test indicators and shown in Table 5.

\section{CONCLUSIONS}

Our present study was an attempt to isolate the potential isolates from the Kaladhi,
Table 5. Evaluation of Co-aggregation ability of isolates with test indicators

\begin{tabular}{lcccc}
\hline Isolates & $\begin{array}{c}E . \\
\text { faecalis }\end{array}$ & $\begin{array}{c}\text { S. } \\
\text { dysgalactiae }\end{array}$ & $\begin{array}{c}P . \\
\text { aeruginosa }\end{array}$ & Mean \\
\hline K1 & 35.23 & 29.21 & 46.82 & 37.08 \\
K2 & 23.21 & 41.24 & 13.00 & 25.81 \\
K3 & 14.5 & 32.18 & 13.23 & 19.97 \\
K4 & 31.23 & 16.25 & 4.01 & 17.61 \\
K5 & 18.2 & 15.32 & 21.44 & 18.32 \\
K6 & 9.2 & 26.21 & 21.32 & 18.91 \\
K7 & 34.2 & 18.03 & 12.1 & 21.44 \\
K8 & 42.52 & 16.34 & 21.74 & 26.86 \\
K9 & 28.42 & 15.32 & 21.3 & 21.68 \\
\hline
\end{tabular}

a traditional fermented food of northwest Himalayas. Among all of the isolates, L. paracasei subsp. Tolerans showed outstanding results by exhibiting antimicrobial substances and have the ability to survive at the acidic medium of the stomach. These isolates could be considered as a potential probiotics due to their antagonistic effect and can be used in nutraceutical or functional foods due to their therapeutic effect.

\section{ACKNOWLEDGMENTS}

The authors are grateful to Chandigarh University for providing research facilities.

\section{CONFLICT OF INTEREST}

The authors declare that there is no conflict of interest. 


\section{AUTHORS' CONTRIBUTION}

Both the authors have made a substantial, direct and intellectual contribution to the work, and approved it for publication.

\section{FUNDING}

None.

\section{DATA AVAILABILITY}

All datasets generated or analyzed during this study are included in the manuscript.

\section{ETHICS STATEMENT}

Biosafety assay of the isolates was performed by using blood agar. For its preparation, self-blood $(2.5 \mathrm{~mL})$ was used with the proper care in the presence of a medical practitioner.

\section{REFERENCES}

1. Sharma H, Bajwa J, Manhas S, Sarwan J. Probiotics: A short review. Annals of Tropical Medicine and Health. 2020;23(15). doi: 10.36295/ASRO.2020.231543

2. Bengmark S. Ecological control of the gastrointestinal tract. The role of probiotic flora. Gut. 1998;42(1):2-7. doi: 10.1136/gut.42.1.2

3. Shah AA, Liu Z, Qian C, Wu J, Sultana N, Zhong X. Potential effect of the microbial fermented feed utilization on physicochemical traits, antioxidant enzyme and trace mineral analysis in rabbit meat. $J$ Anim Physiol Anim Nutr. 2020;104(3):767-775. doi: 10.1111/jpn.13252

4. Cencic A, Chingwaru W. The role of functional foods, nutraceuticals, and food supplements in intestinal health. Nutrients. 2010;2(6):611-625. doi: 10.3390/ nu2060611

5. Sharma H, Bajwa J. Potential Role and Mechanism of Probiotics. Annals of the Romanian Society for Cell Biology. 2021;3616-3624.

6. Aneja RP, Mathur BN, Chandan RC, Banerjee AK. Technology of indian milk products: handbook on process technology modernization for professionals, entrepreneurs and scientists. Dairy India Yearbook. 2002.

7. Bukhari SAA, Pathak V, Bhat ZF, Ahmed SR. Effect of ambient storage on the quality characteristics of Kaladhi-an acid coagulated milk product. American Journal of Food Technology, 2012;7(4), 192-203.

8. Ahmad SR, Pathak V, Bhat ZF, Bukhari SSA. Efficacy of sorbic acid on the storage quality of Kaladhi-An acid coagulated milk product. J Food Sci Technol. 2014;51(12):4040-4046. doi: 10.1007/s13197-0130962-6

9. Bukhari SAA, Pathak V, Bhat ZF, Ahmed SR. Efficacy of acetic acid as coagulant in the preparation of Kaladhia hard and dry cheese variety. Indian Journal of Veterinary Research (The). 2013;22(2):40-51.

10. Sgouras D, Maragkoudakis $\mathrm{P}$, Petraki K, et al. In vitro and in vivo inhibition of Helicobacter pylori by Lactobacillus casei strain Shirota. Appl Environ Microbiol. 2004;70(1):518-526. doi: 10.1128/ AEM.70.1.518-526.2004

11. Marakoudakis PA, Papadelli M, Georgalaki M, et al. In vitro and in vivo safety evaluation of the bacteriocin producer Streptococcus macedonicus ACA-DC 198. Int J Food Microbiol. 2009;133(1):141-147. doi: 10.1016/j. ijfoodmicro.2009.05.012

12. Barefoot SF, Klanhammer TR. Detection and activity of lactacin B, a bacteriocin produced by Lactobacillus acidophilus. Appl Environ Microbiol. 1983;45(6):18081815. doi: 10.1128/aem.45.6.1808-1815.1983

13. Shah AA, Qian C, Wu J, et al. Effects of natamycin and Lactobacillus plantarum on the chemical composition, microbial community, and aerobic stability of Hybrid pennisetum at different temperatures. RSC Advances. 2020;10(15):8692-8702. doi: 10.1039/DORA00028K

14. Shah AA, Xianjun $Y$, Zhihao D, Junfeng L, Shao T. Isolation and molecular identification of lactic acid bacteria from King grass and their application to improve the fermentation quality of sweet Sorghum. World J Microbiol Biotechnol. 2018;34:4. doi: 10.1007/ s11274-017-2387-2

15. Patil MM, Pal A, Anand T, Ramana KV. Isolation and characterization of lactic acid bacteria from curd and cucumber, Indian Journal of Biotechnology, 2010;9:166-172

16. Kerni AN. Duggar delicacy Posted on $6 / 07 / 2014$ by Daily excelsior. 2014. www.dailyexcelsior.com

17. Handoo J. Kaladi cheese, a local delicacy in the hills (Ramnagar, Udhampur) of Jammu and Kashmir. Sustainable Livelihood for Hills-Policy and Institutional Arrangements for Kalari Cheese in the Hills of Jammu and Kashmir. A report submitted to Center for Civil Society, New Delhi. 2009.

18. Choi KH, Lee H, Lee S, Kim S, Yoon Y. Cheese microbial risk assessments-a review. Asian-Australasian Journal of Animal Sciences. 2016;29(3):307-314. doi: 10.5713/ ajas.15.0332

19. Del Re B, Sgorbati B, Miglioli M, Palenzona D. Adhesion, autoaggregation and hydrophobicity of 13 strains of Bifidobacterium longum. Lett Appl Microbiol. 2000;31(6):438-442. doi: 10.1046/j.13652672.2000.00845.x 